\title{
An evaluation of the Monosticon rapid slide test diagnosis of infectious mononucleosis
}

\author{
G. L. SCOTT AND C. J. PRIEST \\ From the Department of Haematology, Louis Jenner Laboratories, St Thomas' Hospital and Medical School, \\ London
}

SYNOPSIS A new rapid slide test for the detection of infectious mononucleosis heterophile antibody has been compared with the Paul-Bunnell absorption test. Out of 200 sera, 46 were seropositive for infectious mononucleosis by the Paul-Bunnell test and 43 of these were detected by the Monosticon test; the three Monosticon-negative sera were of low titre. There was no problem with false positive reactions due to heterophile antibody not specific for infectious mononucleosis.

A number of rapid tests for the detection of the heterophile antibody found in infectious mononucleosis have been devised and this report is concerned with the evaluation of another such testthe Monosticon rapid slide test (Organon). This test is designed for use with capillary blood as well as serum so that it can be used to give an instant result in situations where access to laboratory services is not readily available. This paper deals mainly with the serum test, although a smaller comparative trial using capillary blood is also described.

\section{Material and Methods}

\section{PROCEDURE}

Serum specimens were obtained from patients thought, on clinical grounds, to have infectious mononucleosis. The Monosticon test and the PaulBunnell absorption test were applied to all sera. In addition, a Monosticon test was done using capillary blood from 30 patients; in all these cases serum was obtained for a Monosticon test and Paul-Bunnell absorption test. White blood cell and differential counts were done for every patient. Blood samples were obtained at varying periods after the onset of symptoms, and in a few cases, where the first result was equivocal, a further sample was obtained after an interval.

\section{PATIENTS}

The patients came mainly from three sources-a nurses' clinic, the Student Health Service, and a general practitioner referral service, the remainder came from the outpatient departments and wards of the Hospital.

Received for publication 25 May 1972.
BLOOD SAMPLES

The Monosticon test was performed on the day of collection and sera were stored for not more than $\mathbf{4 8}$ hours at $4^{\circ} \mathrm{C}$ before the Paul-Bunnell test was done. All positive sera were then stored at $-20^{\circ} \mathrm{C}$ until the end of the trial for re-testing if necessary. Capillary blood was obtained by finger prick and the Monosticon test done immediately.

\section{MONOSTICON RAPID SLIDE TEST}

The commercially available kit comprises a book of test papers on which the test is performed, a stable suspension of $30 \%$ horse and $70 \%$ sheep erythrocytes, and a stable extract of guinea-pig kidney tissue. The erythrocytes, which provide a source of antigen, are dehaemoglobinized and then coloured blue by the addition of dye, so that a positive result is shown by the appearance of dark blue clumps.

One volume (approximately $0.03 \mathrm{ml}$ ) of unheated serum is placed in the test circle and 1 volume of guinea-pig kidney extract added and mixed well with a disposable stirrer. One volume of the sheep/horse cell antigen is added and again mixed well. The test slide is rocked gently for two minutes and observed for the presence of agglutination. The procedure for capillary blood is similar except that the initial volume of blood is larger (approximately $0.06 \mathrm{ml}$ ). Each new batch of Monosticon reagents was titrated against a reference serum of known titre to ensure that the sensitivity of the test was unaltered.

\section{PAUL-BUNNELL ABSORPTION TEST}

The method used was that described by Dacie and Lewis (1968) based on the technique of Barrett (1941), except that the volumes were adjusted to give an initial dilution of 1 in 7 for the absorbed and 
non-absorbed sera. This was necessary to make this test comparable with the Monosticon test, the sensitivity of which is adjusted to detect infectious mononucleosis antibody when present in a titre of 56 or greater. The screening test was performed first, followed by the quantitative test if this was positive. All sera used in this test were inactivated by heating at $56^{\circ} \mathrm{C}$ for 30 minutes. Each new batch of reagents was standardized against a positive serum of known titre.

CRITERIA FOR THE DIAGNOSIS OF

INFECTIOUS MONONUCLEOSIS

The Paul-Bunnell absorption test was considered to be positive for infectious mononucleosis if the unabsorbed serum showed a sheep cell agglutination titre of at least 56 and if the titre fell by not more than three tubes after absorption with guinea-pig kidney and at least four tubes after absorption with ox red cells (Davidsohn and Lee, 1969). If the unabsorbed titre was 28, incomplete absorption with guinea-pig kidney and complete removal with ox red cells was taken as presumptive evidence for infectious mononucleosis. The white cell changes considered to be characteristic of infectious mononucleosis were a lymphocytosis of at least $4500 / \mathrm{cmm}$ of which a significant number were atypical in appearance.

\section{Results}

The Monosticon and Paul-Bunnell tests were done on 200 sera (Table I). Forty-three sera gave a

\begin{tabular}{llll}
\hline & \multicolumn{2}{l}{$\begin{array}{l}\text { Paul-Bunnell Absorption } \\
\text { Screening Test }\end{array}$} \\
\cline { 2 - 3 } & Positive & Negative \\
\cline { 2 - 3 } & 43 & 0 \\
Positive & 22 & 135 \\
\hline
\end{tabular}

Table Results of Paul-Bunnell absorption screening test compared with Monosticon test for 200 sera

positive result with both these tests and the differential absorption titre was diagnostic for infectious mononucleosis. Twenty-two sera had a positive Paul-Bunnell absorption test but the Monosticon test was negative. For these 22 sera the differential absorption titre had the pattern of Forsmann antibodies in 15 cases, and serum sickness antibodies in four cases. Of the three remaining sera, two had a titre of 56 with an absorption titre pattern diagnostic for infectious mononucleosis, and one had a titre of 28 but the antibody was not absorbed by guineapig kidney but completely removed by ox red cells- presumptive evidence for infectious mononucleosis. Further specimens were obtained from the last patient and one of those with a titre of 56 and the tests were repeated. In both cases the Monosticon $\underset{\vec{N}}{\overrightarrow{3}}$ test and the absorption test were positive. Thus, of the 200 sera tested, 46 had serological evidence of $\frac{}{0}$ infectious mononucleosis and 43 of these were $\frac{\bar{\sigma}}{\sigma}$ detected by the Monosticon slide test. The three that were not detected by this test were of low titre, although two of them did have titres of 56 which is the limit of sensitivity of the test. These three sera were collected early in the disease but all three patients had white cell changes suggestive of infectious mononucleosis.

The 43 Monosticon positive sera had unabsorbed titres of between 56 and 28000 , and the 22 Monosticon-negative-Paul-Bunnell absorption test-positive sera had titres of between 14 and 1800 . It ${ }_{\omega}^{\infty}$ will be noted that the Monosticon test failed to react 을 with heterophile antibodies not specific for infectious mononucleosis, although they were present in high $c$ titre.

Of the 43 patients giving a positive Monosticon test, 40 had haematological findings suggestive of glandular fever and the remaining three had unconvincing white cell changes although two developed $\overrightarrow{0}$ them later.

Of the 30 capillary blood tests only four wers positive, although 10 serum tests on the same patien were positive. Two capillary tests gave doubtfuI positives but these patients had negative serum tests. The titres of the six sera, not detected by the capillary test, ranged from 56 to 900 .

\section{Comment}

The best serological test for infectious mononucleosis remains the Paul-Bunnell-Davidsohn differential absorption test but this is time-consuming and, as it is more economical to use batch testing, there may be an interval of several days before the results are available. Hence, there is a real need for a reliable, rapid test which can differentiate between the antibody found in infectious mononucleosis and other heterophile antibodies. A number of these tests have been devised and some have proved satisfactory in clinical use (Davidsohn and Lee, 1969; Basson and Sharp, 1969). It is essential that rapid tests include absorption with guinea-pig kidney extract to differentiate the infectious mononucleosis antibody from other heterophile antibodies. The use of horse erythrocytes instead of sheep erythrocytes has been recommended to increase the sensitivity of the test, especially when antibody is present in low titre (Lee, Davidsohn, and Slaby, 1968). The Monosticon test includes absorption with 
guinea-pig kidney extract and a mixture of horse and sheep erythrocytes. The serum test would seem to be satisfactory for the detection of most cases of infectious mononucleosis although it may not be sensitive enough to detect antibody in low titre. There does not appear to be any problem with false positive results due to the presence of high titre heterophile antibody not associated with infectious mononucleosis. The test is rapid and simple to perform and the blue staining of the erythrocytes makes reading of agglutination easy. It is a useful addition to the available rapid tests for the diagnosis of infectious mononucleosis but it is essential that controls are set up with the test and for this reason, in laboratory practice, batch testing is more economical.

Although the sample is small, the capillary test would seem to be less satisfactory, as six of these tests were negative although the serum test was positive and the antibody was present in high titre. The wisdom of encouraging serological tests, how- ever simple, in clinics or surgeries without proper laboratory facilities and without the use of proper controls is debatable.

We should like to thank Dr H. G. Webb for his cooperation with the capillary blood tests and for making available information on patients under his care. We would like to thank Organon Laboratories for the generous supply of Monosticon test kits.

\section{References}

Barrett, A. M. (1941). The serological diagnosis of glandular fever (infectious mononucleosis): a new technique. J. Hyg. (Lond.), 41, 330-343.

Basson, V., and Sharp, A. A. (1969). Monospot: a differential slide test for infectious mononucleosis. J. clin. Path., 22, 324-325.

Dacie, J. V., and Lewis, S. M. (1968). Practical Haematology, 4th ed., p. 527. Churchill, London.

Davidsohn, I. and Lee, C. L. (1969). The clinical serology of infectious mononucleosis. In Infectious Mononucleosis, edited by R. L. Carter and H. G. Penman, pp. 117-200. (Blackwell, Oxford and Edinburgh).

Lee, C. L., Davidsohn, I., and Slaby, R. (1968). Horse agglutinins in infectious mononucleosis. Amer. J. clin. Path., 49, 3-11. 